\title{
High density banana/rubber intercrops have no negative effects on component crops under the smallholder conditions
}

\author{
A M W K Senevirathna*, C M Stirling**, V H L Rodrigo*, P D Pathirana* and \\ P K W Karunathilake* \\ * Rubber Research Institute of Sri Lanka, Dartonfield, Agalawatta, Sri Lanka \\ ** CAZS Natural Resources, College of Natural Sciences, Bangor University, Gwynedd, LL57 \\ $2 U W$, United Kingdom
}

Received 3 May 2010: Accepted 17 June 2010

\begin{abstract}
To test high density banana/rubber intercropping systems under more extensive management conditions, on-farm studies were undertaken in the two major agroclimatic zones of Sri Lanka where rubber is grown; the wet and intermediate zones. Two high density banana planting systems comprising two (RBB) and three (RBBB) rows of banana planted between the rows of rubber, were tested against the recommended intercrop planting system of one row of banana to one row of rubber $(R B)$. In addition, two fertiliser regimes for banana were used in which fertiliser was either ( $i$ ) added at the recommended rate (urea 2: super phosphate 1: muriate of potash 3; $450 \mathrm{~g}$ per plant at 4 month intervals) or (ii) no fertiliser was added. Depending on the quality of field management (level of weeding, damage by animals, personal interest and record maintenance) by farmers, well and poorly managed sites were identified.

Irrespective of climatic conditions, crop performance showed that intercropping had no detrimental effect on growth of either crop, even in the RBBB system. Instead, growth of rubber in all intercrops was superior to that of the sole crop $(R)$. Application of fertiliser to the banana crop in the intercrops significantly improved the growth of banana but had no significant effect on rubber growth. There was no evidence of any nutrient deficiencies in banana, as measured by foliar nutrient concentration, in treatments where no fertiliser was added to banana in the intercrop indicating that banana is suitable crop for intercropping under low input conditions typical of that found on smallholdings.
\end{abstract}

Key words: banana, intercropping, on-farm, planting density, rubber, smallholder

\section{Introduction}

Although commercial rubber (Hevea brasiliensis Muell. Arg.) cultivation began with large scale plantations, it has spread to smallholder farms with more than $80 \%$ of world rubber now 
produced on smallholdings of less than 2 ha (IRSG, 2009). As for many perennial cash crops, rubber has a long gestation period of $c a$. five years posing a significant problem to resource poor farmers. Intercropping with shorter duration crops provides practical means of alleviating the problem of the lack of income during the immature phase of rubber. In Sri Lanka, the most popular system among smallholders is the intercropping of banana (Musa spp.) with rubber (1-3 years), accounting for ca. $80 \%$ of intercrops grown by rubber farmers (Rodrigo et al., 2001a). Onstation experiments have provided sufficient evidence to prove that banana/rubber intercropping systems are more productive and profitable than sole cropped rubber (Rodrigo et al., 1997; 2001a; 2005). Moreover, it was possible to increase the planting density of banana up to $200 \%$ from the original levels in banana/rubber intercrops without any detrimental effect on either crop (Rodrigo et al., 1997). Instead, both component crops benefited from high density planting systems.

Application of research findings from on-station experiments to the farmers' field is sometimes limited by constraints related to land and socio-economic factors (Chambers et al., 1989). Unlike on-station experiments, optimum growth requirements are rarely achieved on-farm and in particular, expensive items (e.g. inorganic fertiliser) are not applied unless they are essential (Rodrigo et al., 2001a). With their limited resources, smallholder farmers do not aim to maximise the profits onfarm, instead they try to achieve their livelihood goals by balancing land use with available inputs (financial, social and agricultural). Consequently, it is often difficult to predict the on-farm performance of cropping systems based on the results from on-station trials.

The objective of the present study was to investigate the suitability of high density banana/rubber intercrops to conditions on-farm. Treatments included three planting densities (three, two and one row of banana planted between rows of rubber), two fertiliser applications (inorganic fertiliser either added or not added to the banana plants in the intercrops) and two climatic zones (wet zone and intermediate zone). In addition, the results were analysed in relation to two broad management conditions observed on-farm, i.e. well managed and poorly managed sites based on farmers' interest on weeding, damage by animals and record maintenance. Social issues associated with this on-farm evaluation have been dealt with elsewhere (Tennakoon, 2002; Rodrigo et al. 2003).

\section{Materials and Methods}

\section{Site selection}

In Sri Lanka, rubber is mostly grown in two major agro-climatic regions - the low country Wet (WL) and Intermediate (IL) zones. The amount and the distribution of rainfall differ in these two areas with the WL receiving an annual rainfall of $c a .3200 \mathrm{~mm}$ with only limited dry spells whilst the IL has 
a distinct dry period of $c a$. 5-6 months and a total annual rainfall limited to $c a$. $1300 \mathrm{~mm}$ (DOA, 2003). Four administrative districts, two from each zone, were selected for the study (Table 1). One village was chosen in each district. In each village, farmers were interviewed to assess the suitability of the site (minimum land size of 0.4 ha.) and willingness to participate in the study. Selected farmers were supplied with planting materials and inorganic fertiliser to apply as per the treatments.

\section{Treatment layout}

The main treatment imposed was planting density of banana, with intercrops planted in an additive series of one (RB), two (RBB) and three (RBBB) rows of banana between the rows of rubber. The RB system represented the traditional recommended planting whilst $\mathrm{RBB}$ and RBBB were the high density systems of planting that had been previously tested on-station (Rodrigo et al., 1997). A plot of sole crop rubber (SR) was also planted for comparison. Rubber plants raised in polythene bags ( $c a .8$ months old) were planted at spacing of $2.4 \mathrm{~m} \mathrm{x}$ $8.1 \mathrm{~m}$ within and between rows. The within row spacing for banana was $3.0 \mathrm{~m}$ whilst the between row spacing varied with planting density; $4.0 \mathrm{~m}$ for the single, $2.7 \mathrm{~m}$ for the double and $2.0 \mathrm{~m}$ for the triple rows of banana. In addition to the main treatments, two fertiliser management regimes for banana were applied at the recommended rate (FER; $450 \mathrm{~g}$ per plant of urea 2: super phosphate 1: muriate of potash 3 mixture at four monthly intervals) or not at all (NFER).

Treatments were arranged in a Split-Plot design at each smallholding where planting densities of banana and fertiliser levels were main and sub plots, respectively. It was not feasible to incorporate all the possible combinations of main (SR, RB, RBB and RBBB) and sub plot treatments (FER and NFER) in every smallholding due to the limited land available. Therefore, the main and sub plots were planted to accommodate at least 4 combinations at each experimental site. According to the quality of field management (level of weeding, damage by animals, personal interest and record maintenance - Rodrigo et al. 2003) well (Well) and poorly (Poor) managed sites were identified. These two categories of management were also considered as two treatments.

Table 1. Details of the smallholdings selected for the on-farm study

\begin{tabular}{lllcc}
\hline Agro-climatic zone & District & Village & Number of sites & Land size (ha) \\
\hline \multirow{2}{*}{ Wet zone (WL) } & Kegalle & Pannila & 2 & 0.8 \\
& Kalutara & Kobawaka & 3 & 1.2 \\
Intermediate zone & Moneragala & Pallekiruwa & 7 & 2.8 \\
(IL) & Hambantota & Bookendayaya & 2 & 0.8 \\
\hline
\end{tabular}




\section{Plant material and establishment}

Rubber plants bud-grafted with the genotype, RRIC 100 were supplied to the farmers selected for the study. Farmers themselves planted the rubber trees provided, in the holes dug to a length, width and depth of $0.60 \mathrm{~m} \times 0.60$ $\mathrm{m} \times 0.75 \mathrm{~m}$. Banana rhizomes with a pseudostem of $c a .0 .3 \mathrm{~m}$ length from the genome group ' $A A B$ ' were also provided to farmers depending on the number of plants that could be incorporated in the site and were planted in the holes dug to a length, width and depth of $0.6 \mathrm{~m} \times 0.6 \mathrm{~m} \times 0.6$ $\mathrm{m}$ according to the design of the main plots, after treating them with a fungicide mixture (DOA, 1995). The recommended mixture of fertiliser for banana was supplied to farmers and was applied to the fertilised treatment of banana (FER) according to the Department of Agriculture's recommendations (DOA, 1995). Recommended annual amounts of fertilisers for rubber (Samarappuli, 2001) were also supplied to farmers by the relevant Rubber Development Department (RDD) offices under the rubber subsidy scheme. Farmers were left with the responsibility of managing their intercrops including weeding, protecting plants from animals and watering when necessary.

\section{Weather data}

Daily rainfall data were recorded at one of the experimental sites in each of the selected villages (Table 1) using locally made rain gauges (NERD, Sri Lanka).

\section{Soil nutrient analysis}

Analysis of N, P, K, Mg, Ca, pH and organic carbon content were carried out for $0-0.3 \mathrm{~m}$ depth at each experimental site prior to planting. Analysis of $\mathrm{K}, \mathrm{Mg}$ and $\mathrm{Ca}$ was done using the ammonium acetate exchangeable method, N, P and organic carbon were analysed with an auto-analyser (Bran and Lubbe Analyser System, UK) using the Modified Bray II and Walkley-Black methods, respectively (Singh and Ratnasingam, 1971a). Bulk density of the soil was also measured by taking soil core samples from $0-0.3 \mathrm{~m}$ depth and from four corners and the middle of each site used to take samples for nutrient analyses.

\section{Foliar nutrient analysis}

In order to determine whether high density intercropping had any effect on the nutrient status of rubber and banana, foliar nutrient analyses were carried out in the RBBB and SR main plots. From the RBBB main plot, FER and NFER sub-plots were selected in order to account for the effect of fertiliser application to banana. Two plants randomly selected from each crop from the FER and NFER treatments and in addition, two rubber trees from the SR were sampled. Five leaves (3 leaflets per leaf) of rubber were harvested from the topmost, fully matured, green leaf whorl from each plant. In the case of banana, two leaf samples ( $c a .0 .3 \mathrm{~m} \mathrm{x}$ $0.3 \mathrm{~m}$ ) from both sides of the midrib of the topmost third, fully matured, green leaf from each plant at 8-10 months of 
age were harvested. Samples were collected and placed in perforated polythene bags to prevent moisture condensation, labelled and then brought to the laboratory within 24 hours. Two well (Well) and two poorly (Poor) managed experimental sites from both WL and IL zones were selected for nutrient analyses.

Samples were dried in a force draft oven to a constant weight $\left(80^{\circ} \mathrm{C}\right)$ and $0.2 \mathrm{~g}$ of a dried samples were taken for nutrient analyses. $\mathrm{N}, \mathrm{P}$ and $\mathrm{K}$ were determined simultaneously by the Auto Analyser (Bran and Lubbe Analyser System, UK) whilst $\mathrm{Ca}$ and $\mathrm{Mg}$ were assessed by Atomic Absorption Spectrophotometry (GBC, Australia; Singh and Ratnasingam, 1971b).

\section{Non-destructive growth analyses}

Stem girth at a height of $10 \mathrm{~cm}$ from the ground for both rubber and banana was recorded for each treatment and at each experimental site at 5-6 month intervals. In addition, plant height of banana was measured at 5-6 month intervals. As planting and measurement dates were different in the WL and IL, girth and height of banana at 14 months after planting (MAP) was taken for the comparison between the agro-climatic zones and sites. In the case of rubber, girth increment (GI) for a 10-month period was calculated in order to compare the growth performance of rubber between zones and sites during the mother crop period of banana. To compare the growth performances of intercropped and sole crop rubber, relative girth increment (RGI) of treatments, i.e. the GI of the treatments relative to the GI of the sole crop was calculated.

\section{Statistical analysis}

For the analysis of stem basal girth and height of banana, and GI and RGI of rubber, a split plot design (SAS Institute Inc., Cary, NC, USA) was used and as data were unbalanced, a General Linear Model (GLM) was applied. Mean separation of treatments was performed with the least square mean (LSMEANS) for the comparison of treatment effects. For the foliar nutrient analyses, analysis of variance (ANOVA) was used whilst the mean separation of treatments was done using the Duncan's multiple range test (DMRT).

\section{Results}

Climatological conditions and site characteristics

During the 14 month study period a mean total rainfall of $4410 \mathrm{~mm}$ was received at the WL sites compared with $2079 \mathrm{~mm}$ for IL (Fig. 1). The total number of rainy days for the same period was 181 and 126 in the WL and IL, respectively. Rainfall was fairly widely distributed in the WL, throughout the experimental period whilst in the IL rains were mainly confined to the Northeast monsoon (September to February; Fig. 1). 


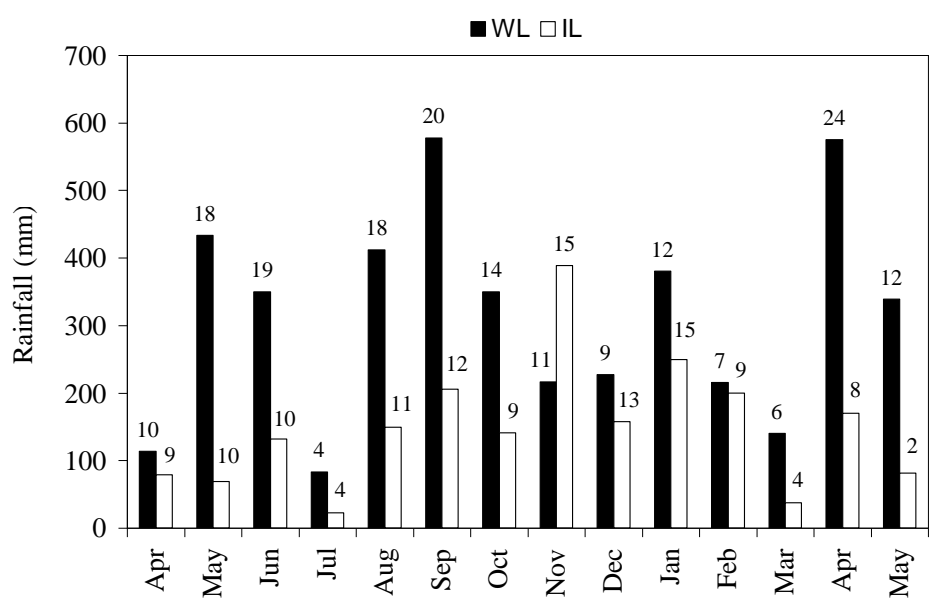

Fig. 1. Summary of rainfall for the period 14 months at the experimental sites located in the low country wet zone (WL) and in the intermediate zone (IL) of Sri Lanka. Data represent means of daily readings at two sites in each agro-climatic zone, and the numbers at the top of the columns represent the number of rainy days in each month

Soil nutrient analyses prior to planting banana showed higher levels of $\mathrm{pH}, \mathrm{P}$, $\mathrm{K}, \mathrm{Mg}$ and $\mathrm{Ca}$ in the IL compared with the WL $(p \leq 0.05)$ whereas, soil organic carbon (OC) and $\mathrm{N}$ were similar in both agro-climatic zones (Table 2). Although, the soil bulk density was significantly higher $(p \leq 0.01)$ in the WL compared to the IL, absolute differences were small $\left(0.06 \mathrm{~g} \mathrm{~cm}^{-3}\right)$.

Table 2. Soil characteristics at the experimental sites in the wet zone (WL) and in the intermediate zone (IL) for $0-0.3 \mathrm{~m}$ soil depth. Data represent means of 5 replicates from each agro-climatic zone except for bulk density where $n=50$ for each zone. Means within the same row and with different superscripts are significantly different at $p \leq 0.05$

\begin{tabular}{lll}
\hline Soil property & WL & IL \\
\hline Bulk density $\left(\mathrm{g} \mathrm{cm}^{-3}\right)$ & $0.914 \pm 0.043^{\mathrm{a}}$ & $0.852 \pm 0.032^{\mathrm{b}}$ \\
$\mathrm{pH}$ & $4.44 \pm 0.12^{\mathrm{b}}$ & $5.56 \pm 0.17^{\mathrm{a}}$ \\
$\%$ Organic carbon & $1.42 \pm 0.07^{\mathrm{a}}$ & $1.32 \pm 0.08^{\mathrm{a}}$ \\
$\% \mathrm{~N}$ & $0.24 \pm 0.02^{\mathrm{a}}$ & $0.23 \pm 0.01^{\mathrm{a}}$ \\
$\mathrm{P}(\mathrm{ppm})$ & $8.26 \pm 1.32^{\mathrm{b}}$ & $31.41 \pm 5.97^{\mathrm{a}}$ \\
$\mathrm{K}(\mathrm{ppm})$ & $166.49 \pm 50.06^{\mathrm{b}}$ & $284.50 \pm 17.68^{\mathrm{a}}$ \\
$\mathrm{Mg}(\mathrm{ppm})$ & $35.61 \pm 6.78^{\mathrm{b}}$ & $182.50 \pm 26.21^{\mathrm{a}}$ \\
$\mathrm{Ca}(\mathrm{ppm})$ & $149.00 \pm 40.02^{\mathrm{b}}$ & $187.00 \pm 26.21^{\mathrm{a}}$ \\
\hline
\end{tabular}




\section{Growth of rubber and banana}

Analysis of stem girth increment (GI) of rubber over a 10 -month period indicated no significant effect of planting density of banana and agro-climatic zones $(p>0.05)$ on growth (Fig. 2a). However, GI of rubber was significantly higher $(p \leq 0.001)$ in Well compared with the
Poorly managed sites. The relative girth increment (RGI) of rubber, i.e. the ratio of GI of intercrop treatments to the sole rubber crop showed values over 1 in most of the treatments and was significantly higher in the WL (Fig. 2b).
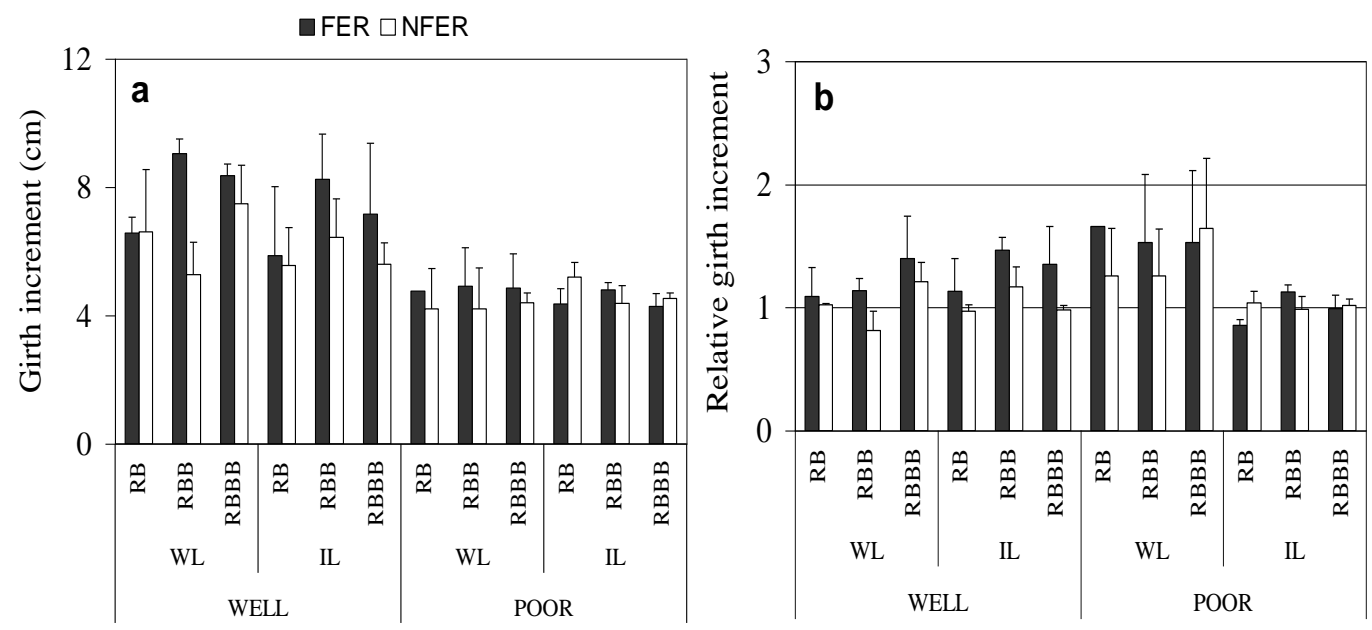

Fig. 2. Growth performance of rubber on-farm; (a) stem girth increment (measured at a height of $10 \mathrm{~cm}$ from the ground) over a 10 month period and (b) girth increment relative to the girth increment of sole crop rubber in well (Well) and poorly (Poor) managed banana/rubber intercrops where $\mathrm{RB}, \mathrm{RBB}$ and $\mathrm{RBBB}$ respectively refer to the single, double and triple rows of banana planted between rubber rows in the wet zone (WL) and in the intermediate zone (IL) of Sri Lanka. FER and NFER represent respectively the sub-plots in which banana was either fertilised or not fertilised. Data represent means \pm s.e.m. of an average of 45 and 81 replicate plants per treatment respectively from the WL and IL, and 3 and 4 Well, and 2 and 5 Poor managed experimental sites in the WL and IL respectively. 
Table 3. Summary of the statistical analysis of the effects of agro-climatic zone (ZONE), Well and Poor management (MANG), planting density of banana (BD), fertiliser application to banana (FER) and their interactions on girth increment (GI) and relative girth increment (RGI) of rubber over a 10 month period, in addition to plant girth and height of banana at 14 months after planting. Probability values are shown and emboldened where effects are significant at $p \leq 0.05$ level. $C V$ is the coefficient of variation (\%)

\begin{tabular}{lcccc}
\hline \multirow{2}{*}{$\begin{array}{l}\text { Source of } \\
\text { variation }\end{array}$} & GI & RGI & Girth & Height \\
\cline { 2 - 5 } MANG & $\mathbf{0 . 0 0 0 1}$ & 0.117 & $\mathbf{0 . 0 0 0 1}$ & $\mathbf{0 . 0 0 0 1}$ \\
ZONE & 0.474 & $\mathbf{0 . 0 1 2}$ & 0.223 & $\mathbf{0 . 0 1 1}$ \\
BD & 0.615 & 0.719 & 0.782 & 0.813 \\
FER & 0.114 & 0.074 & $\mathbf{0 . 0 0 0 1}$ & $\mathbf{0 . 0 0 0 1}$ \\
ZONE x BD & 0.552 & 0.172 & 0.058 & 0.185 \\
BD x FER & 0.295 & 0.775 & 0.425 & 0.506 \\
MANG x ZONE & 0.381 & $\mathbf{0 . 0 0 2}$ & 0.112 & 0.115 \\
MANG x BD & 0.462 & 0.682 & 0.497 & 0.717 \\
\%CV & 29.26 & 32.24 & 20.82 & 25.95 \\
\hline
\end{tabular}

As shown by the stem basal girth of banana at 14 MAP, growth of banana has not been affected by either agroclimatic zones or planting density of banana. Nevertheless, girth of banana increased significantly $(p \leq 0.01)$ with application of fertiliser (Fig. 3a). Stem height of banana was significantly higher in the IL $(p \leq 0.05)$ and in the subplots where fertiliser was applied $(p \leq 0.01$; Fig. 3b). Both plant height and stem basal girth at 14 MAP were significantly higher in the Well relative to Poorly managed sites $(p \leq 0.001)$.

Foliar nutrient status of rubber and banana

Figures 4 and 5 summarise the foliar N, $\mathrm{P}, \mathrm{K}, \mathrm{Mg}$ and $\mathrm{Ca}$ status of rubber and banana, respectively in the high density intercrop (RBBB). Foliar \% $\mathrm{P}$ and $\% \mathrm{Mg}$ contents of rubber were significantly higher $(p \leq 0.05)$ in the IL whilst the $\% \mathrm{~N}$ content was higher $(p \leq 0.05)$ in the WL. There were no differences in $\% \mathrm{~K}$ and $\% \mathrm{Ca}$ of rubber between agro-climatic zones (Fig. 4). Only the $\% \mathrm{~N}$ content was significantly higher $(p \leq 0.05)$ in the Well managed sites compared to that of Poorly managed sites (Fig. 4). Foliage nutrient content of rubber did not significantly differ between fertilised, non-fertilised and sole cropped main plots $(p>0.05)$. In banana only the \%P content was significantly higher $(p \leq 0.01)$ in the IL compared to that of the WL (Fig. 5). No differences in any of the foliar nutrients of banana were observed in either fertilised and nonfertilised treatments or the Well and Poorly managed sites (Fig. 5). 

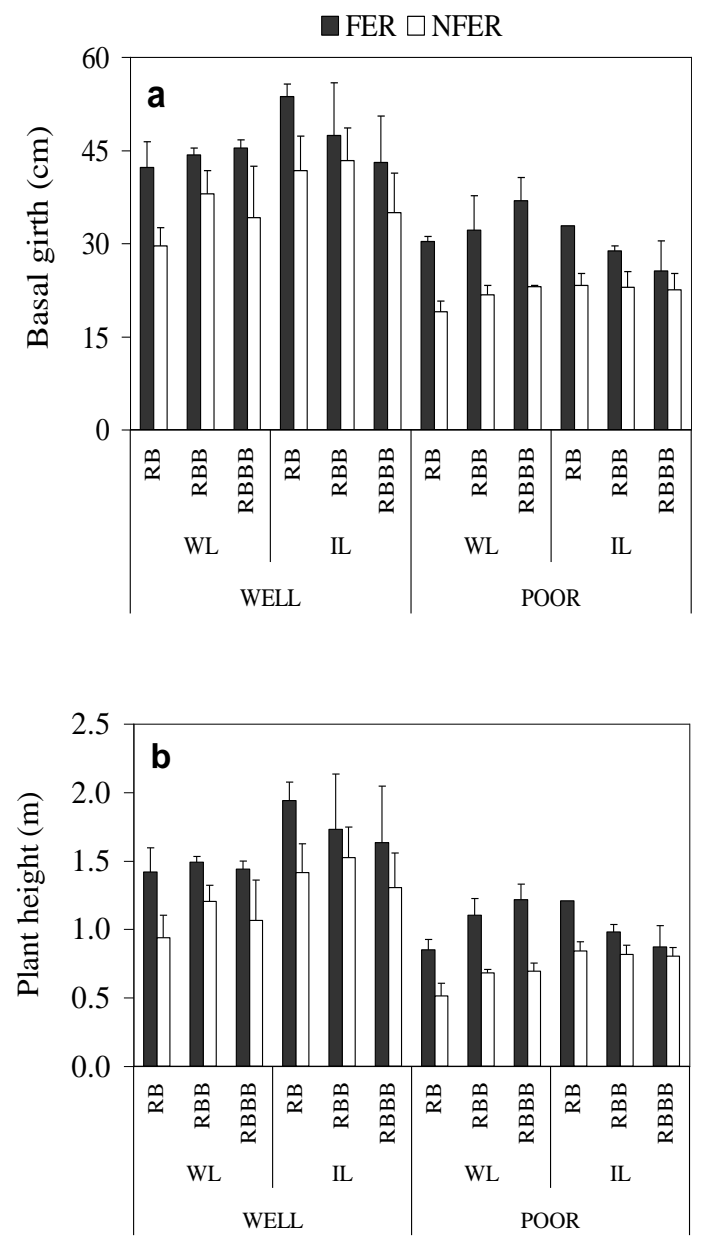

Fig. 3. Growth performances of banana on-farm; (a) stem basal girth (measured at a height of $10 \mathrm{~cm}$ from the ground) and (b) plant height at 14 months after planting in well (Well) and poorly (Poor) managed banana/rubber intercrops farmer fields where RB, RBB and $\mathrm{RBBB}$ respectively refer to the single, double and triple rows of banana between two rows of rubber in the wet zone (WL) and in the intermediate zone (IL) of Sri Lanka. FER and NFER represent respectively the sub-plots in which banana was either fertilised or not fertilised. Data represent means \pm s.e.m. of an average of 135 and 243 replicate plants per treatment respectively from the WL and IL, and 3 and 4 Well, and 2 and 5 Poor managed experimental sites from WL and IL respectively 

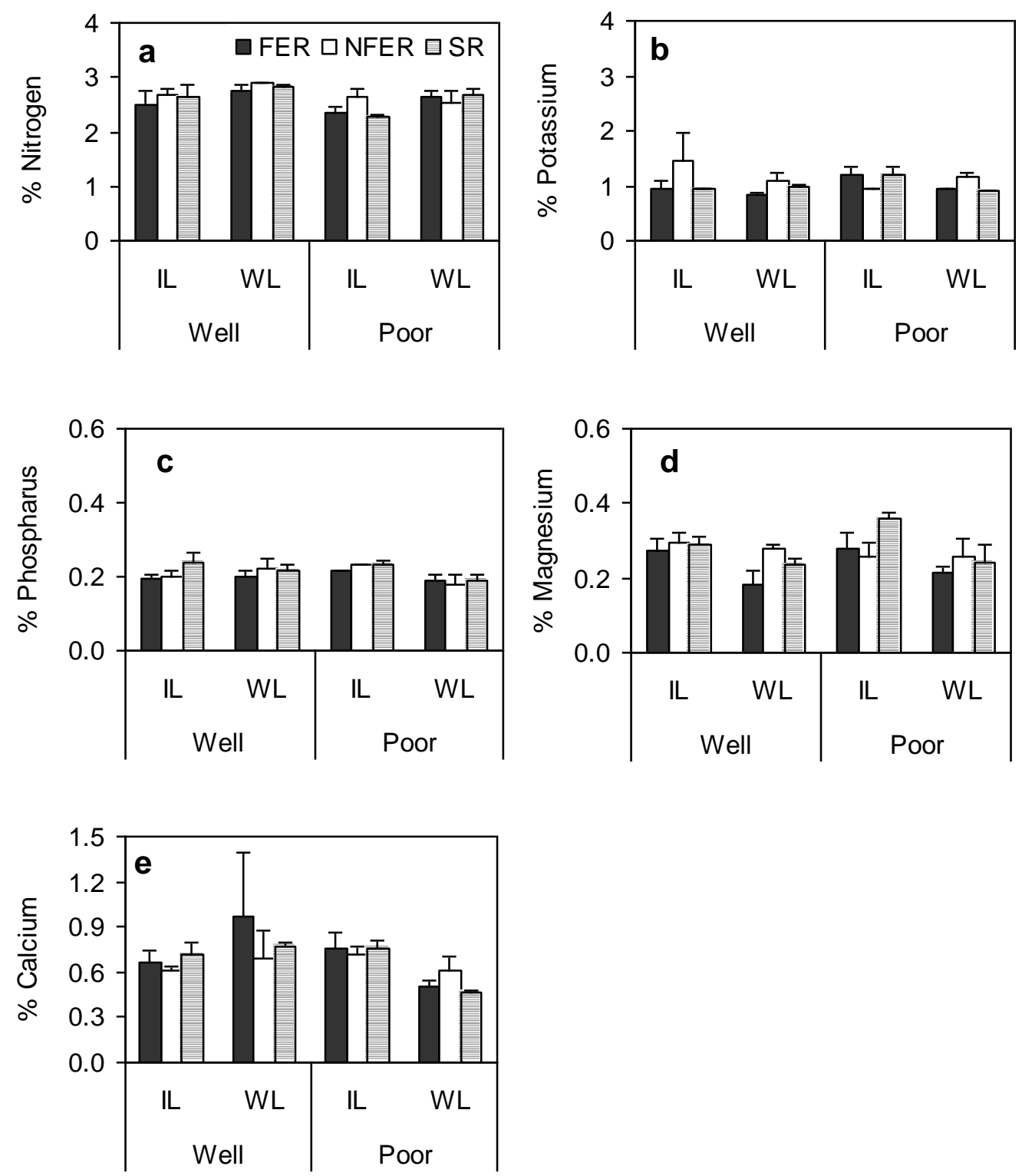

Fig. 4. Foliar nutrient status of rubber; (a) \% nitrogen (b) \% potassium (c) $\%$ phosphorus (d) $\%$ magnesium and (e) \% calcium in the sub-plots where fertiliser was either applied (FER) or not (NFER) to banana in the triple row banana/rubber intercrops and in sole crop rubber (SR) treatments. Analyses were done selecting two Well and two Poor managed sites in each agro-climatic zone, wet (WL) and intermediate zones (IL) of Sri Lanka 

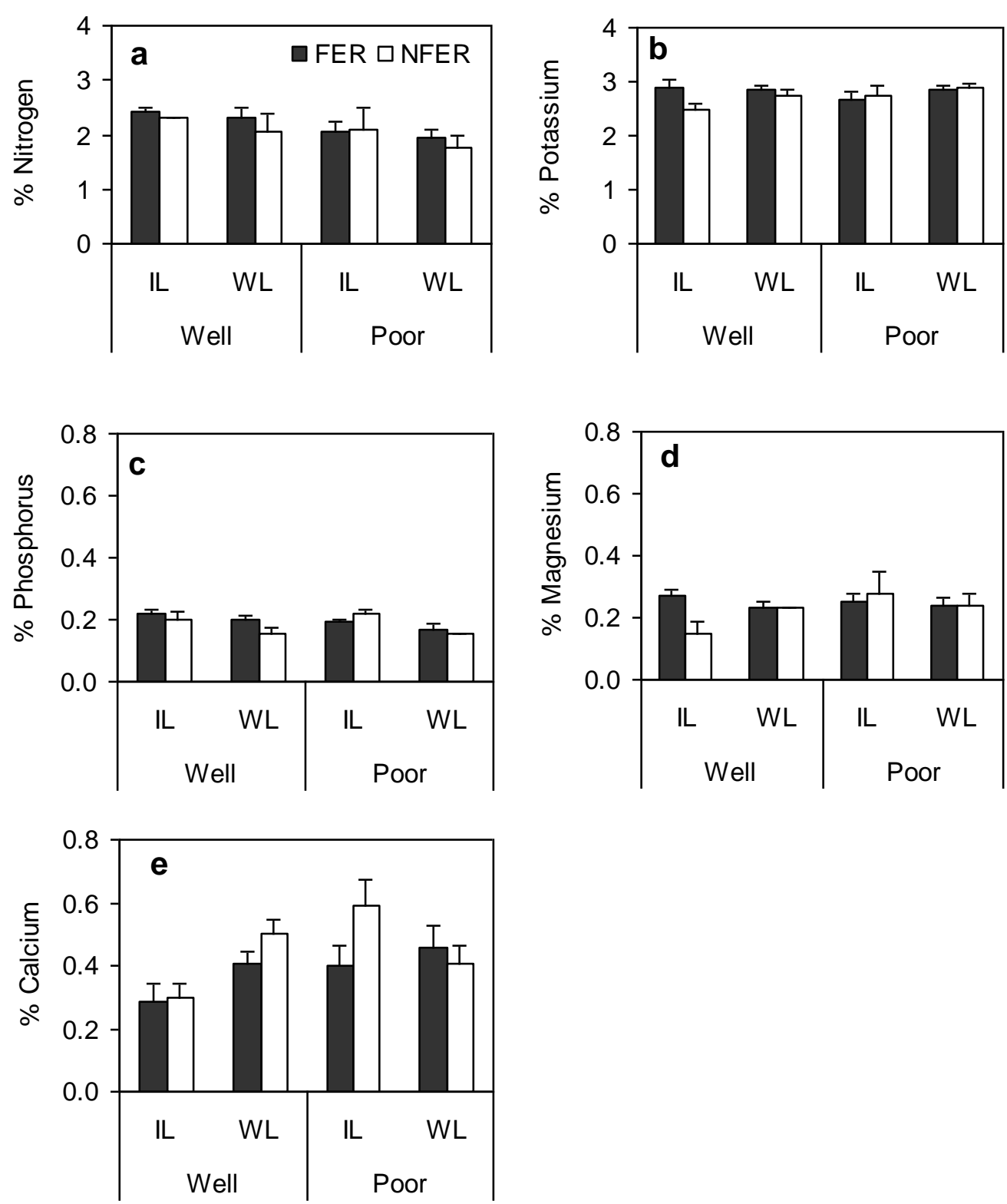

Fig. 5. Foliar nutrient status of banana; (a) $\%$ nitrogen (b) $\%$ potassium (c) $\%$ phosphorus (d) $\%$ magnesium and (e) \% calcium in the sub-plots where fertiliser was either applied (FER) or not (NFER) to banana in the triple row banana/rubber intercrops. Analyses were done selecting two Well and Poor managed sites in each agro-climatic zone, wet (WL) and intermediate zones (IL) of Sri Lanka 
Table 4. Summary of the statistical analysis of the effects of agro-climatic zone (ZONE), Well or Poor management (MANG), fertiliser application to banana (FER) and their interactions on foliar nutrients: nitrogen $(N)$, phosphorus $(P)$, potassium $(K)$, magnesium $(\mathrm{Mg})$ and calcium $(\mathrm{Ca})$ of rubber and banana in the treatment with triple rows of banana between the rows of rubber. Probability values are shown and emboldened where effects are significant at $p \leq 0.05$ and $C V$ is the coefficient of variation (\%)

\begin{tabular}{lccccc}
\hline Source of variation & $\mathbf{N}$ & $\mathbf{P}$ & $\mathbf{K}$ & $\mathbf{M g}$ & Ca \\
\hline Rubber & & & & & \\
ZONE & $\mathbf{0 . 0 1 7}$ & $\mathbf{0 . 0 4 8}$ & 0.279 & $\mathbf{0 . 0 0 6}$ & 0.672 \\
MANG & $\mathbf{0 . 0 2 5}$ & 0.601 & 0.866 & 0.572 & 0.226 \\
FER & 0.403 & 0.381 & 0.321 & 0.134 & 0.791 \\
ZONE x MANG & 0.967 & $\mathbf{0 . 0 3 6}$ & 0.806 & 0.891 & $\mathbf{0 . 0 4 7}$ \\
ZONE x FER & 0.404 & 0.559 & 0.896 & 0.180 & 0.770 \\
MANG x FER & 0.801 & 0.673 & 0.285 & 0.327 & 0.587 \\
\%CV & 7.4 & 11.1 & 24.8 & 16.6 & 29.2 \\
\hline Banana & & & & & \\
ZONE & 0.230 & $\mathbf{0 . 0 0 3}$ & 0.148 & 0.935 & 0.333 \\
MANG & 0.069 & 0.332 & 0.638 & 0.289 & 0.082 \\
FER & 0.409 & 0.224 & 0.258 & 0.400 & 0.228 \\
ZONE x MANG & 0.851 & 0.526 & 0.749 & 0.415 & $\mathbf{0 . 0 4 0}$ \\
ZONE x FER & 0.554 & 0.141 & 0.394 & 0.405 & 0.444 \\
MANG x FER & 0.702 & 0.136 & 0.086 & 0.198 & 0.863 \\
\%CV & 13.9 & 10.8 & 5.7 & 22.5 & 22.5 \\
\hline
\end{tabular}

\section{Discussion}

The major differences in climatic conditions between the wet and intermediate agro-climatic zones of Sri Lanka were the source of rainfall together with the total amount and distribution over the year (Fig. 1). High and evenly distributed rainfall in the WL might be one of the factors in acidifying soils as indicated by the low $\mathrm{pH}$ compared to that in the IL (Table 2). With no large variation in mean temperatures between the two zones (DCS, Sri Lanka, 2005), the amount and the distribution of rain were of the main climatic determinants of crop growth between the two zones. The significantly higher soil $\mathrm{P}, \mathrm{K}$ and $\mathrm{Mg}$ content in the IL compared to the WL was most likely explained by the fact that slash and burn agriculture (locally known as 'Chena' cultivation) was practised before introducing rubber to IL lands. In support of this Giardina et al.(2000) have reported that ,frequent burning results in the addition of high amount of ash to the soil, thereby raising levels of soil nutrients, particularly $\mathrm{K}$; and also in acidic soil, $\mathrm{P}$ levels are often low (Wong and Lin, 2000). 
The growth of rubber was affected neither by planting density of banana, agro-climatic zone nor the application of fertiliser to banana (Fig. 2). These results suggest that rubber had access to the required amount of nutrients and so did not compete for the extra fertiliser added to the intercrops, at early stages of growth, even in the high density banana/rubber intercrops (RBBB) where three times as much fertiliser was applied (on a unit area basis) compared to the early recommended single row system. On the other hand, rubber was not detrimentally affected by intercropping, even at high densities of banana on-farm with no additional fertiliser indicating complementarity of both crops in intercropping, as Rodrigo et al. (2005) observed on-station. In rubber, RGI was generally above unity on most occasions showing again the advantage of having banana as an intercrop (Fig. 2b). Plant height and stem basal girth of banana were increased with the direct application of fertiliser to banana (Fig. 3). This indicates that if fertiliser is applied to banana then productivity will be increased, although the normal practice on-farm is not to apply fertiliser for banana (Rodrigo et al., 2001a; Senevirathna, 2001). The RBBB, even without fertiliser to banana, did not affect the growth of rubber and so this system would prove to be far more profitable than the traditionally recommended RB intercrop system. The observed on-farm growth performance of both rubber and banana when intercropped agreed with the previous on-station results (Rodrigo et al.,1997, 2005) and suggest that the high density intercropping system is robust, with productivity advantages been sustained on-farm and across a range of climatic conditions. The results also dispel the notion that the greater amount of fertiliser applied to banana in the RBBB system (on a unit area basis) may have caused the improved growth of rubber observed in earlier intercropping studies (Rodrigo et al., 1997) and suggest that planting distances in the RBBB system do not cause any inter-specific competition for nutrients during the period of intercropped banana (1-2 years).

The present study lent greater insight into the effects of fertiliser on banana, which had not been examined in previous experiments, with application of fertiliser resulting in improved growth of banana at all densities tested (Fig. 3). During interviews at the beginning of the study, farmers had expressed doubt about the success of the 3-row banana/rubber intercropping system (Senevirathna, 2001) because they believed that competition for nutrients would be too intensive resulting in poor growth of both crops. The results disprove this. The density of banana in the RBBB treatment was $c a$. 1500 plants per hectare and was less than the standard recommendation for sole crop banana (1666 plants $\mathrm{ha}^{-1}$ ) or the high densities (2222 plants $h^{-1}$ ) used in the sole crop banana plantations (Robinson and Nel, 1988; 1989). 
Therefore, the highest density of banana used in this research did not reach even the recommended density for sole crop plantations, explaining why increasing planting density from one to three rows had no detrimental effect on banana growth.

Although in this on-farm research, inputs such as experimental design, planting material and fertiliser were supplied to farmers, decision on weeding and upkeep of the land were the responsibility of the farmer. From observations on quality of crop management such as level of weeding, damage by animals, personal interest and record maintenance (Rodrigo et al., 2003), Well and Poorly managed sites were identified. When analysing the growth performance of rubber and banana, and taking into account the quality of management, Well managed fields were found to be significantly superior in terms of growth of both crops. This indicates that agronomic practices such as clearing weeds, allowing weed litter to decompose on the land, loosening soil around plants etc. (Senevirathna, 2001) are important in terms of promoting growth of both crops, most probably by restricting competition with weeds for available soil nutrients (Samarappuli, 2001) and improving soil physical properties. In general, Well and Poor management levels were the result of a combination of socio-economic factors such as priority for farming activities, other income sources, price and demand for commodities, availability and cost of labour, general interest on farming and personnel attitudes (Tennakoon, 2002, Rodrigo et al. 2001b, 2003).

Foliar nutrient analysis of rubber showed high $\mathrm{P}$ and $\mathrm{Mg}$ contents in the IL compared with the WL (Fig. 4), which most probably reflected the very high inherent soil $\mathrm{P}$ and $\mathrm{Mg}$ contents of the soil (Table 2). High leaf $\mathrm{N}$ content in rubber of Well managed fields may have been due to the improved uptake of fertiliser by rubber in the absence of competition from weeds and possibly due to the improved soil physical properties as a result of good agronomic management. However, high growth performance of fertilised and Well managed banana were not reflected in the leaf nutrient analysis indicating that even without added fertiliser, soil nutrients were sufficient to enable banana plants to develop without deficiency symptoms. Although foliar nutrient concentrations were the same, fertilised and Well managed plants were bigger than non-fertilised and Poorly managed plants (Senevirathna, 2001) and therefore, total plant nutrients would be greatest in these treatments. High leaf $\mathrm{P}$ content in IL most probably reflected the inherently high soil $\mathrm{P}$ level. The foliar $\mathrm{K}$ content of banana was higher than that of rubber (Turner and Barkus, 1981; 1983; Yogaratnam et al., 1984), reflecting the greater importance of $\mathrm{K}$ to growth of banana (Turner and Barkus, 1981; 1983). Nutrients in leaves, trash and fruits did not vary much except higher levels of $\mathrm{K}$ were found in fruits and $\mathrm{Ca}$ in leaves, when 
expressed in terms of percentage of dry matter (Turner and Barkus, 1983). According to this and as the present foliar nutrient concentration was analysed before fruit set, leaves provided a reasonable representation of the concentration of nutrients in banana plant as a whole. And also the foliar nutrient concentrations in the present study were similar to those previously observed (Turner and Barkus, 1981; 1983).

Analysis of the growth performance of rubber and foliar nutrient contents in the RBBB treatment clearly showed that the benefits of intercropping cannot simply be explained by rubber accessing the extra nutrients applied to the component banana intercrop. In terms of the growth performance of banana, fertiliser application had a beneficial effect on growth. There was no evidence that the relative growth of intercropped versus sole cropped rubber and the effects of planting density of banana was influenced by agro-climatic zone; the main effect been the quality of agronomic management which was mainly dependent upon the farmers' interest. It can therefore be concluded that the banana/rubber intercropping does not have any detrimental effect on either crop even with high planting densities of banana on-farm, and is suitable for smallholder farming systems in both the wet and intermediate zones of Sri Lanka.

\section{Acknowledgements}

We wish to thank first the farmers involved in the research for their immense support given throughout towards the success of this project. Our thanks are extended to the staff of the Soils and Plant Nutrition Department of the Rubber Research Institute of Sri Lanka for their assistance in nutrient analysis and to Dr. (Mrs.) Wasana Wijesuriya, Biometrician of the institute for her support in analysing data. This publication is an output from the project, R7212 of Plant Science Research Programme funded by the UK Department for International Development (DFID) for the benefit of developing countries. The views expressed are not necessarily those of DFID.

\section{References}

Chambers, R, Pacey, A and Thrupp, L A (1989). Farmer First: Farmer Innovation and Agricultural Research. Intermediate Technology Publication, London, UK.

DCS (2005). Statistical Abstract of the Democratic Socialist Republic of Sri Lanka. Department of Census and Statistics, Ministry of Finance and Planning of Sri Lanka.

DOA (1995). Planting Banana. Department of Agriculture, Sri Lanka.

DOA (2003). Map of Agro-ecological Regions of Sri Lanka. Natural Resource Management Centre, Department of Agriculture, Sri Lanka. 
Giardina, C P, Sanford, R L and Dockersmith, I C (2000). Changes in soil phosphorus and nitrogen during slash and burn clearing of a dry tropical forest. Journal of Soil Science Society of America 64 (1), 399-405.

IRSG (2009). Rubber Statistical Bulletin 64 (1-3). International Rubber Study Group, UK.

Robinson, J C and Nel, D J (1988). Plant density studies with banana ( $c v$. Williams) in a subtropical climate I. Vegetative morphology, phenology and plantation microclimate. Journal of Horticultural Science 63 (2), 303-313.

Robinson, J C and Nel, D J (1989). Plant density studies with banana (cv. Williams) in a subtropical climate II. Components of yield and seasonal distribution of yield. Journal of Horticultural Science 64 (2), 211-222.

Rodrigo, V H L, Stirling, C M, Teklehaimanot, $\mathrm{Z}$ and Nugawela, A (1997). The effect of planting density on growth and development of component crops in rubber/banana intercropping systems. Field Crops Research 52, 95108.

Rodrigo, V H L, Stirling, C M, Narampanawa, R M A K B and Herath, P H M U (2001a). Intercropping of immature rubber in Sri Lanka: present status and financial analysis of rubber intercrops planted at three densities of banana. Agroforestry Systems 51, 35-48.

Rodrigo, V H L, Thennakoon, S and Stirling, C M (2001b). Priorities and objectives of smallholder rubber growers and the contribution of intercropping to livelihood strategies: a case study from Sri Lanka. Outlook on Agriculture 30 (4), 261-266.

Rodrigo V H L, Stirling, C M, Tennakoon, T M S P K, Senevirathna, A M W K and
Pathirana, P D (2003). Technology refinement of rubber/banana intercropping using a farmer participatory approach. Tropical Agricultural Research and Extension 6, 77-84.

Rodrigo, V H L, Stirling, C M, Silva, T U K and Pathirana, P D (2005). The growth and yield of rubber at maturity is improved by intercropping with banana during the early stage of rubber cultivation. Field Crops Research 91, 23-33.

Samarappuli, L (2001). Management of soil and weed infestation (Chapter 3), Nutrition (Chapter 15). In: Handbook of Rubber Vol. 1: Agronomy, (Eds. L.M.K. Tillekeratne and A. Nugawela). pp. 2639, pp. 156-175, Rubber Research Institute of Sri Lanka, Sri Lanka.

Senevirathna, A M W K (2001). The influence of farmer knowledge, shade and planting density on smallholder rubber/banana intercropping in Sri Lanka. PhD Thesis, University of Wales, United Kingdom.

Singh, M M and Ratnasingam, K (1971a). Manual of Laboratory Methods of Chemical Soil Analysis. Analytical Chemistry Division, Rubber Research Institute of Malaya, Kuala Lumpur.

Singh, M M and Ratnasingam, K (1971b). Manual of Laboratory Methods of Chemical Leaf Analysis. Analytical Chemistry Division, Rubber Research Institute of Malaya, Kuala Lumpur.

Tennakoon, T M S P K (2002). Influence of crop profitability, market, labour and land on smallholder cropping systems in rubber growing areas of Sri Lanka. PhD Thesis, University of Wales, United Kingdom.

Turner, D W and Barkus, B (1981). Nutrient concentrations in the leaves of a range of 
banana varieties grown in the subtropics. Fruits 36 (4), 217-222.

Turner, D W and Barkus, B (1983). The uptake and distribution of mineral nutrients in the banana in response to supply of $\mathrm{K}, \mathrm{Mg}$ and $\mathrm{Mn}$. Fertiliser Research 4 (1), 89-99.

Wong, J Y and Lin, H C (2000). Effect of soil $\mathrm{pH}$, nitrogen form and VA mycorrhiza infection on the acquisition of soil phosphorus by the paprika plant. Food Science and Agricultural Chemistry 2 (3), 169-173.
Yogaratnam, N, Silva, F $\mathrm{P} \quad \mathrm{W}$ and Weerasuriya, S M (1984). Recent developments in the nutrition of Hevea in Sri Lanka. Proceedings of the International Rubber Conference 1 (1), 207-247. 17-19 September 1984, Colombo, Sri Lanka.

Address for correspondence: Dr A M W K Senevirathna, Botanist, Rubber Research Institute of Sri Lanka, Dartonfield, Agalawatta, Sri Lanka.

e-mail: wasanthasen@gmail.com, 